\title{
Impact of Hypothermia upon Chondrocyte Viability and Cartilage Matrix Permeability after 1 Month of Refrigerated Storage
}

\author{
Kelvin G.M. Brockbank ${ }^{a, b, c}$ Eliza Rahn ${ }^{a}$ Gregory J. Wright ${ }^{d} \quad$ Zhenzhen Chen $^{a}$ Hai Yao ${ }^{c, d}$ \\ ${ }^{a}$ Cell \& Tissue Systems, Inc., North Charleston, SC, \\ ${ }^{\mathrm{b}}$ Institute for Bioengineering and Bioscience, Georgia Institute of Technology, Atlanta, GA, \\ ${ }^{c}$ Department of Regenerative Medicine and Cell Biology, Medical University of South Carolina (MUSC), Charleston, SC, \\ ${ }^{\mathrm{d}}$ Clemson-MUSC Joint Bioengineering Program, Department of Bioengineering, Clemson University, Charleston, SC, USA.
}

\section{Keywords}

Preservation · Hypothermia $\cdot$ Metabolism .

Cartilage $\cdot$ Chondrocyte $\cdot$ Matrix $\cdot$ Storage $\cdot$ Permeability .

Viability

\section{Summary}

Background: The purpose of this research was to assess the extracellular matrix and chondrocytes of articular cartilage during refrigerated storage and to determine whether changes could be detected in the time frame that cartilage is stored for clinical use. Methods: Porcine cartilage was stored as either bisected femoral heads with bone attached or plugs without the underlying bone in culture medium with fetal bovine serum for 1 month at $4{ }^{\circ} \mathrm{C}$. Metabolic activity was tested using a resazurin reduction method on intact tissue and viable cell recovery after enzymatic tissue digestion at each time point. Cartilage plug permeability was evaluated by measuring electrical conductivity. Results: Storage in culture medium provided good cartilage viability and metabolic function for 7 days; however, significant changes were observed in femoral heads $(p<0.05)$. All mean chondrocyte assessment values were $<30 \%$ of fresh controls at 28 days. Cartilage plugs tended to perform better after 7 days of storage than the femoral heads and retained significantly higher metabolic activity (mean $=94.5 \%$ vs. $70.5 \% ; p<0.05$ ). Cartilage plugs demonstrated consistent changes in electrical conductivity after 28 days of storage $(p<0.05)$. Conclusion: Refrigerated storage of cartilage results in both loss of chondrocyte viability and matrix permeability.

\section{Schlüsselwörter}

Biologische Konservierung · Hypothermie - Stoffwechsel . Knorpel · Chondrozyten · Matrix · Lagerung · Permeabilität . Viabilität

\section{Zusammenfassung}

Zielsetzung: Ziel dieser Untersuchungen war eine Charakterisierung der extrazellulären Matrix und der Knorpelzellen im Gelenkknorpel während der gekühlten Lagerung, um mögliche Veränderungen im Gewebe während eines klinisch relevanten Lagerzeitraums aufzuzeigen. Methoden: Knorpelgewebe vom Schwein wurde entweder in Form von halbierten Oberschenkelköpfen mit adhärentem Knorpel oder als reine zylindrische Knorpelstücke ohne Knochen gelagert. Die Lagerung erfolgte in Zellkulturmedium mit fetalem Kälberserum bei $4^{\circ} \mathrm{C}$ über $30 \mathrm{Tage}$. Zu jedem Messzeitpunkt wurde die Stoffwechselaktivität mittels eines Resazurin-Reduktionsassays in intaktem Gewebe quantifiziert sowie die Regeneration der Zellen nach enzymatischer Verdauung des Knorpelgewebes untersucht. Die Knorpelpermeabilität wurde anhand der elektrischen Leitfähigkeit bestimmt. Ergebnisse: Bei Lagerung in Zellkulturmedium blieben die Viabilität und Stoffwechselfunktion des Knorpels für 7 Tage gut erhalten, an Oberschenkelköpfen wurden dagegen signifikante Veränderungen beobachtet. Sämtliche gemittelten Analysenwerte der Knorpelzellen betrugen nach 28 Tagen Lagerung nur noch weniger als $30 \%$ im Vergleich zu nativen Kontrollen. Knorpelstücke erzielten nach 7 Tagen tendenziell bessere Ergebnisse als Oberschenkelköpfe. Diese wiesen eine signifikant bessere Stoffwechselaktivität auf $(94,5 \%$ vs. $70,5 \% ; p<0,05)$. Die Knorpelstücke zeigten nach 28 Tagen Lagerung dauerhafte Veränderungen in der elektrischen Leitfähigkeit $(p<0,05)$. Schlussfolgerung: Die Lagerung von Knorpel bei $4^{\circ} \mathrm{C}$ führt sowohl zu einer Abnahme der Chondrozytenviabilität als auch der Matrixpermeabilität.

\section{KARGER}

Fax +497614520714

Information@Karger.de

www.karger.com (c) 2011 S. Karger GmbH, Freiburg

Accessible online at:

www.karger.com/tmh 


\section{Introduction}

Fresh donor-derived osteochondral plugs and intact osteochondral grafts harvested within $24 \mathrm{~h}$ of donor death and banked at $4{ }^{\circ} \mathrm{C}$ for up to 42 days are employed clinically for repair of cartilage defects. Plugs are employed in mosaicplasty procedures for smaller defects less than $3 \mathrm{~cm}$ wide and less than $1 \mathrm{~cm}$ deep. Osteochondral allograft transplantation has been an effective treatment option with promising long-term clinical outcomes for larger focal posttraumatic defects in the knee for young, active individuals [1]. There were 15,797 allogeneic human articular cartilage procedures performed in the USA during 2006 [2].

Review of the literature generally advocates articular cartilage storage for 2-6 weeks. However, in our experience cells typically survive less than $48 \mathrm{~h}$ of cold storage in culture media without specially designed hypothermic storage solutions [3]. There are exceptions, such as myofibroblasts in heart valve leaflets [4] or chondrocytes in articular cartilage. There have been reports on chondrocytes in articular cartilage of humans [5-9] and several animal species including rabbits [10], rats $[11,12]$, dogs [13, 14], miniature pigs [15], sheep [16], cattle $[17,18]$, and non-human primates [9], demonstrating that chondrocytes survive days or weeks of hypothermic storage in their natural extracellular matrix. The take-home message from these studies is that chondrocyte viability decreases with time in storage and that the rate of decline is influenced by the storage solution employed. However, many of these studies used fluorescent assays to determine the impact of storage, and doubt has been cast upon the accuracy of such assays for chondrocytes in intact cartilage [19]. Another concern, if most of the cells are viable, is the possibility that prolonged storage of cartilage with viable cells might promote the release of enzymes such as metalloproteinases (MMPs), which may impact the permeability of the extracellular matrix (ECM).

Therefore, we initiated research to assess the impact of $4{ }^{\circ} \mathrm{C}$ storage on cartilage cell viability and ECM permeability during storage in tissue culture medium. In this baseline study we employed porcine cartilage comparing large pieces of cartilage (bisected femoral heads) versus cartilage plugs to determine whether or not tissue volume had an impact on chondrocyte viability using two assays. We also assessed cartilage plug permeability by measuring electrical conductivity.

\section{Material and Methods}

No animals were sacrificed for these studies. Bona fide excess tissue was employed. Bona fide excess tissue is a term used to describe animal-derived materials obtained from animals after they have been sacrificed for other uses. Pig knees were procured from adult domestic Yorkshire cross farm pigs $(25-60 \mathrm{~kg})$ at the conclusion of other Institutional Animal Care and Use Committee-approved research projects at the Medical University of South Carolina. The knees were placed in zip lock bags with an iodine solution and transported on ice to our laboratory for aseptic dissection.

\section{Experimental Design}

Porcine femoral cartilage, either bisected femoral heads consisting of both cartilage and bone or cartilage plugs without the underlying bone, were stored in culture medium (DMEM) with $10 \%$ fetal bovine serum (FBS) for 0 (fresh untreated control), 1, 7, or 28 days at $4{ }^{\circ} \mathrm{C}$. The medium was changed weekly.

\section{Viability Assessment}

Chondrocyte metabolic activity was assessed using the resazurin reduction method after storage of the 6-mm discs for 0,7 , or 28 days. The resazurin reduction assay incorporates a water-soluble fluorometric viability oxidation reduction (REDOX) indicator which detects metabolic activity by both fluorescing and changing color in response to chemical reduction of the growth medium. Metabolically active cells reduce resazurin to fluorescing resorufin [20]. Tissue samples were placed in $37^{\circ} \mathrm{C}$ culture conditions for $1 \mathrm{~h}$ to permit adjustment to tissue culture conditions in DMEM plus $10 \%$ FBS. The tissues were then incubated for $3 \mathrm{~h}$ with resazurin working solution. Aliquots of medium were placed in microtiter plate wells and read on a microtiter plate spectrofluorometer at a wavelength of $590 \mathrm{~nm}$. The data is expressed as the mean \pm 1 standard error (SE) relative fluorescent units. Viable cell recovery was determined by trypan blue exclusion after enzymatic tissue digestion. The cells were also plated and cultured with DMEM plus $10 \%$ FBS for 1 week to verify that the chondrocytes were able to adhere and proliferate in vitro.

\section{Biomaterial Testing}

Cartilage plugs were also evaluated for permeability by measuring their electrical conductivity to determine if biomaterial changes were occurring during storage. Specimens were prepared by cutting a 5 -mm cylindrical plug using a corneal trephine from the stored 8-mm diameter cartilage discs. In the first series of experiments, the superior and inferior surfaces of each cylindrical sample were trimmed using a sledge microtome (Leica SM2400, Nussloch, Germany) after adherence to the microtome stage by freezing to ensure flat, parallel surfaces for contact with the conductivity electrodes. The samples $(n=29)$ were tested after $0,1,7$, and 28 days of storage in isotonic phosphate-buffered saline (PBS). In a second series of tests in which samples were tested after 0 and 28 days of storage, the cartilage surfaces were trimmed manually using a sharp blade without freezing. Then conductivity was first tested in isotonic PBS followed by swelling and testing in hypotonic saline $(0.2 \times \mathrm{PBS})$. The height of each specimen was measured with an electrical current-sensing micrometer. The method and apparatus for measuring electrical conductivity of tissues was reported previously [21]. Briefly, the conductivity apparatus consists of two stainless steel current electrodes coaxial to two Teflon-coated $\mathrm{Ag} / \mathrm{AgCl}$ voltage electrodes placed on the top and bottom of a cylindrical nonconductive plexiglass chamber (5 mm diameter). Applying the four-wire method and using a source meter (Model 2400, Keithley Instruments, Inc., Cleveland, OH, USA), the resistance (R) values across the specimens were measured at a low, constant current density of $0.015 \mathrm{~mA} / \mathrm{cm}^{2}$. The electrical conductivity $(\chi)$ values of the specimens were calculated by:

$$
\chi=\frac{h}{R \times A}
$$

where $h$ and $A$ are the height and cross-sectional area of the specimens, respectively. All electrical conductivity measurements were performed in PBS at room temperature $\left(22^{\circ} \mathrm{C}\right)$. Electrical conductivity is a material property of biological tissues. Its value is related to the diffusivity of small ions inside the tissue, which depend on tissue composition and structure $[22,23]$. Using an electrical conductivity method, the effect of matrix composition on solute permeability has been studied in hydrogels and cartilaginous tissues $[24,25]$. In this study, we adopted this method to study the impact of $4{ }^{\circ} \mathrm{C}$ storage on cartilage ECM solute permeability. Moreover, the transport of small solutes (e.g. ions, oxygen, and glucose) 
Fig. 1. Chondrocyte viability during hypothermic storage in cartilage plugs (open bars) and femoral heads (cross hatched bars) assessed by $\mathbf{A}$ resazurin reduction metabolic assay data expressed as the mean RFU/6 mm plug $\pm 1 \mathrm{SE}$ and $\mathbf{B}$ trypan blue exclusion data is expressed as chondrocytes $/ 6 \mathrm{~mm}$ plug $\pm 1 \mathrm{SE}$. * indicates significant differences, $\mathrm{p}<0.05$.

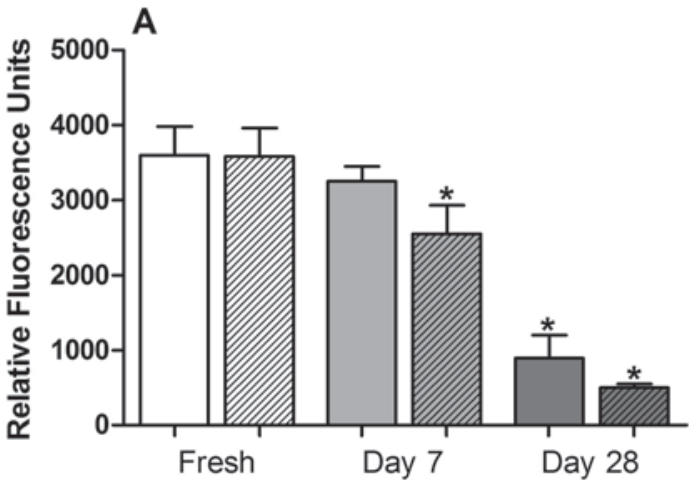

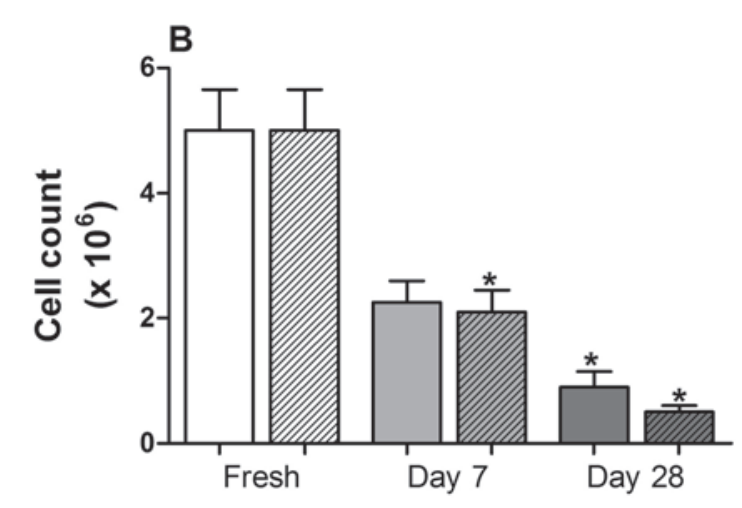

Fig. 2. Representative pictures of trypan blue excluding cells in tissue culture from $\mathbf{A}$ control untreated cartilagederived chondrocytes plated at $10^{5} / \mathrm{ml}$, B 7-day-stored cartilage-derived chondrocytes plated

at $10^{5} / \mathrm{ml}$ and $\mathbf{C} 28$-day-stored cartilage-derived chondrocytes plated at $0.6 \times 10^{5} / \mathrm{ml}$. Phase contrast pictures after one week, in vitro $10 \times$ original magnification, the scale bar equals $100 \mu \mathrm{m}$.

within avascular cartilage tissues mainly depends on diffusion [26]. Therefore, electrical conductivity was selected in addition to cell viability in order to evaluate tissue ECM changes that may affect nutrient transport ability as well as mechanical function in vivo.

\section{Statistical Methods}

One-way ANOVA was conducted to determine differences in mean values of cell count, cell fluorescence units, and electrical conductivity between $0,1,7$, and 28 day treatment groups $(\mathrm{p}<0.05)$. In the final conductivity study $(n=20)$, which focused specifically on fresh and 28-day treatment groups, a paired t-test was used to determine significant differences $(\mathrm{p}<0.05)$.

\section{Results}

Storage in culture medium provides good cartilage viability and metabolic function for 7 days; however, significant changes were observed in femoral heads as early as 1 week (fig. 1). All mean chondrocyte assessment values were $<30 \%$ of fresh controls at 28 days. Cartilage plugs tended to perform better after 7 days of storage than the femoral heads and retained significantly higher metabolic activity ( mean $=94.5 \%$ vs. $70.5 \%$ ). After 7 days of storage the metabolic assay results were consistently higher than the cell isolation results (fig. 1). After completion of the trypan blue viability counts, the cells were plated and cultured. Representative areas in each cul- ture flask photographed after 1 week in culture revealed similar degrees of confluence (fig. 2).

The prepared disc-shaped specimens employing the microtome ( $\mathrm{n}=4$ for each group) had an average height of $2.49 \pm$ $0.57 \mathrm{~mm}$ and a diameter of $5 \mathrm{~mm}$. In the first experiment, fresh cartilage demonstrated a mean conductivity of 12.6 $\mathrm{mS} / \mathrm{cm}$, which decreased significantly to 10.7 and $7.8 \mathrm{mS} / \mathrm{cm}$ at 7 and 28 days of storage [27], respectively. However, further experiments did not demonstrate significant decreases during storage (not shown), and there were no significant differences when data from these experiments were combined $(\mathrm{n}=29$, fig. 3). Therefore, the cartilage plugs failed to demonstrate consistent significant changes in electrical conductivity as a measure of permeability over 28 days of storage.

We were however concerned that the method employed to mount the plugs, i.e. freezing to a chuck to trim the tissue, may have obscured differences between the experimental and control groups, particularly because we had seen differences in the first of the four experiments above. Samples from four individual porcine donors were then prepared without freezing, and the superficial layer and deep layer was trimmed from each end of the plug manually. The average height after trimming was $1.55 \pm 0.35 \mathrm{~mm}(\mathrm{n}=20)$. Significant differences were observed for plugs tested in isotonic saline $(\mathrm{p}=0.007)$ and hypotonic saline $(\mathrm{p}<0.0001)$ groups using a paired t-test. 


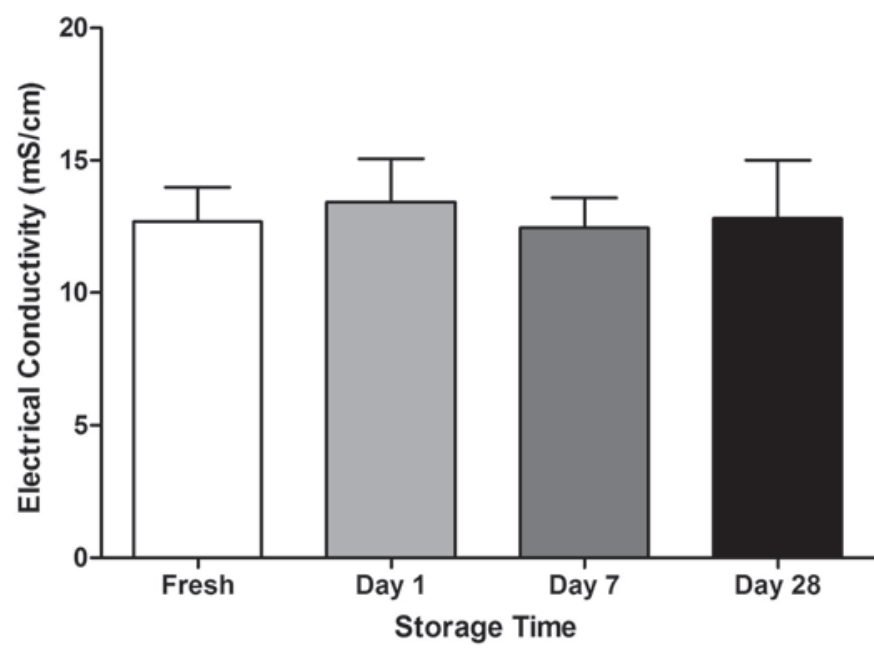

Fig. 3. Impact of hypothermic storage of cartilage on electrical conductivity in isotonic saline. In these experiments the cartilage plug was prepared using freezing stage. There were no statistically significant changes in permeability, $\mathrm{p}=0.139$, the data is expressed as the mean $\pm 1 \mathrm{SD}, \mathrm{n}=29$.

Fig. 4. Comparison of fresh control and 28-day-stored cartilage plug electrical conductivity under isotonic (open bars) and hypotonic (patterned bars) conditions. In these follow-up experiments the cartilage plugs were trimmed without freezing stage and conductivity was assessed first in isotonic saline $(1 \times$ PBS $)$ and

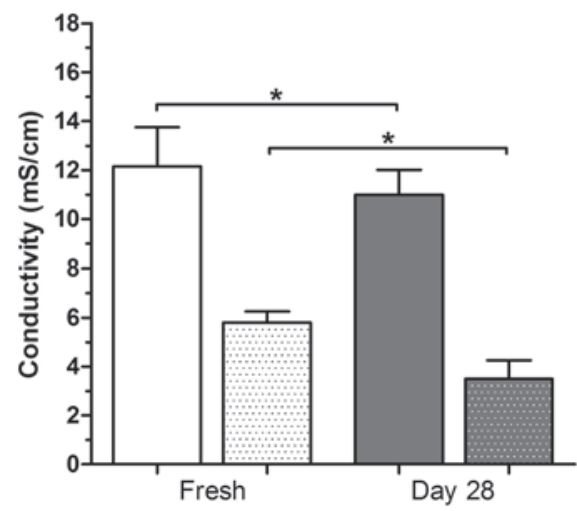

then in hypotonic saline $(0.2 \times$ PBS $)$. The data is expressed as the mean \pm 1 SD and $*$ indicates significant differences at $\mathrm{p}<0.05, \mathrm{n}=20$.

Although the difference was small in the isotonic solution (12.17 vs. $11.0 .6 \mathrm{mS} / \mathrm{cm})$, these differences were significant and were magnified when the samples were swollen in hypotonic solution for testing (5.66 vs. $3.44 \mathrm{mS} / \mathrm{cm}$ ) (fig. 4).

\section{Discussion}

Early studies have suggested that chondrocyte viability at the time of implantation is an important factor in ensuring longterm allograft survival in vivo $[28,29]$. Commercially available fresh osteoarticular allografts are stored for at least 17 days to allow serologic and microbiologic testing prior to implantation because of concerns about potential infection [5, 30]. Chondrocyte viability has been reported to range between 30 and $90 \%$ after 4 days of refrigerated storage [31-32]. However, justification for longer storage is ambiguous [5-7, 15, 30,
$33,34]$, and it is not clear what type of storage solution should be employed.

We found, in agreement with the literature, that storage in DMEM culture medium with $10 \%$ FBS provides good cartilage viability for 7 days. The metabolic assay used to determine the viability of the chondrocytes within intact cartilage provided higher cell viability values at 7 days than the cell isolation studies with trypan blue. In contrast by 28 days the results using the two assays were similar with less than $30 \%$ cell viability (fig. 1). Our interpretation of these results is that many of the chondrocytes may have been damaged at 7 days, resulting in loss during the cell isolation procedures employing collagenase required prior to the determination of cell viability using trypan blue. This may also explain concerns previously expressed regarding the use of fluorescent assays for cartilage storage studies [19]. It is possible that the metabolic assay at this time point is an accurate measure of potential viability if the tissues were implanted rather than subjected to collagenase digestion. The trypan blue-excluding cells from fresh and both 7- and 28-day-stored tissues were able to proliferate and resulted in qualitatively similar cultures after 1 week in vitro (fig. 2).

Bisected femoral heads and much smaller cartilage plugs were compared to evaluate the impact if any of cartilage volume on cell survival. There was a marked tendency for cartilage plugs to demonstrate higher viability values after 7 days of storage than the femoral heads, but it was only statistically significant for metabolic activity (fig. 1). The results after 28 days were similar. These results confirm the use of cartilage plugs for further studies to compare the impact of different storage solutions and additives on chondrocyte survival. This will include comparison of hypothermic storage solutions, such as the University of Wisconsin solution (UW), employed for organ and tissue storage and more complex culture media. UW is an example of 'intracellular-type' preservation solutions which are typically hypertonic and formulated to restrict the passive exchange of water and ions during hypothermia-induced inhibition of cell membrane pumps [reviewed in 35]. An intracellular-type solution usually includes a non-permeating, impermeant anion such as lactobionate or gluconate to partially replace chloride ions in the extracellular space. This provides osmotic support to balance the intracellular oncotic pressure generated by cytosolic macromolecules and their associated counter-ions locked inside the cell. In contrast, saline and culture media are extracellular-type solutions. They are isotonic with a plasma-like complement of ions that mimics the normal extracellular environment of cells. Tissue culture media contain a more complete complement of ions, amino acids, and other metabolites that mimic the extracellular composition of plasma. Most published studies on cartilage hypothermic storage have employed extracellular-type solutions. Onuma et al. [12] compared DMEM, saline, EuroCollins solution, and UW solution to determine which provided the best hypothermic preservation of rat osteochondral tissues. They concluded on the basis 
of two assays and histology that UW solution was the most suitable. Teng et al. [18] clearly demonstrated the positive impact of more complex culture media formulation upon chondrocyte survival. There are other indications in the literature that media supplementation or modification may promote chondrocyte survival. Removal of FBS from storage solutions is also an issue for tissue bank products due to FBS batch variation and the associated health risks $[18,36]$. Extensive research is needed to determine whether intracellular- or extracellulartype solutions are best for chondrocyte preservation in cartilage and to define the optimal solution composition.

Cartilage tissue is comprised of a solid and fluid phase, and it may be treated as a biphasic material. Cartilage executes its role in the body to absorb and distribute joint stresses based on this mechanism. Therefore, the permeability characteristic is an important material property of cartilage that is usually overlooked in contrast to more commonly studied tensile or compressive parameters. Studies of such biomechanics parameters in the literature have consistently failed to demonstrate changes in cold stored cartilage. In our first series of experiments employing isotonic saline during evaluation, we did not observe consistent changes in permeability. However, we saw changes in the first experiment [27], contributing to the negative data in figure 3 , and we previously observed extracellular matrix damage in frozen articular cartilage [37]. Therefore, in order to rule out the possibility that ice formation during trimming of the cartilage plugs had changed sample permeability, we performed another series of experiments comparing 0 and 28 days of storage $(n=20)$. First the samples were tested in isotonic saline $(1 \times \mathrm{PBS})$ and then retested in hypotonic $(0.2 \times \mathrm{PBS})$ saline. Hypotonic saline was used because we hypothesized that it might render the assay system more sensitive to hypothetical ECM changes. The results (fig. 4) demonstrated statistically significant changes during testing in both isotonic and hypotonic saline, and the differences were greater in hypotonic saline than in isotonic saline. Hypotonic solution made the tests more sensitive due to increased tissue swelling which magnifies changes in the highly charged ECM [21]. Further experiments to determine the time course of these permeability changes are needed. In addition, laser scanning microscopy [37] or RAMAN spectroscopy may detect changes in collagen structure.

In conclusion, 28-day storage of cartilage results in loss of chondrocyte viability and ECM permeability. Storage methods for clinical cartilage utilization should be carefully evaluated because the tissue may be experiencing clinically significant deterioration over time. We plan further investigation of cartilage cell and biomaterial properties during storage combined with storage solution formulation optimization. Improved storage solutions could result in increased utilization of banked allogeneic cartilage for reconstruction of articular cartilage defects and possibly storage and distribution of tissue-engineered cartilage.

\section{Acknowledgements}

This project was supported by NIH grants DE018741 and AR055775 to HY, a NIH T32 predoctoral fellowship DE017551 to GJW and Industrial Student Internship support from the Georgia Institute of Technology to ER.

\section{Disclosure Statement}

Dr. Brockbank is an owner and employee of Cell and Tissue Systems. Mrs. Chen is also an employee of the company.

\section{References}

1 Gross AE, Ont, O, Kim W, Las Heras F, Backstein D, Safir O, Pritzker MD, KPH: Fresh osteochondral allografts for posttraumatic knee defects: long-term followup. Clin Orthop Relat Res 2008; 466:1863-1870.

2 Worldwide Markets and Emerging Technologies for Tissue Engineering and Regenerative Medicine. InteLab Corporation, Marketing and Technology Reports. January, 2009.

3 Taylor MJ, Brockbank KGM: Frontiers in biopreservation technology: challenges for the storage of living tissues and engineered constructs; in Klatz RM, Goldman R (eds): Anti-Aging Medical Therapeutics, vol 5. Marina Del Rey, Health Quest Publications, 2003, chapter 49, pp 515-526.

$\checkmark 4$ Brockbank KGM, Carpenter JF, Dawson PE: Effects of storage temperature on viable bioprosthetic heart valves. Cryobiology 1992:29:5:537-542.

$>5$ Williams SK, Amiel D, Ball ST, Allen RT, Wong VW, Chen AC, Sah RL, Bugbee WD: Prolonged storage effects on the articular cartilage of fresh human osteochondral allografts. J Bone Joint Surg Am 2003;85:2111-2120.
6 Ball ST, Amiel D, Williams SK, Tontz W, Chen AC, Sah RL, Bugbee WD: The effects of storage on fresh human osteochondral allografts. Clin Orthop Relat Res 2004;418:246-252.

7 Gole MD, Poulsen D, Marzo JM, Ko SH, Ziv I: Chondrocyte viability in press-fit cryopreserved osteochondral allografts. J Orthop Res 2004;22: 781-787.

8 Allen RT, Robertson CM, Pennock AT, Bugbee WD, Harwood FL, Wong VW, Chen AC, Sah RL, Amiel D: Analysis of stored osteochondral allografts at the time of surgical implantation. Am J Sports Med 2005;33:1479-1484.

$\checkmark 9$ Malinin T, Temple HT, Buck BE: Transplantation of osteochondral allografts after cold storage. J Bone Joint Surg Am 2006;88:762-770.

10 Black J, Shadle CA, Parsons JR, Brighton CT: Articular cartilage preservation and storage. II. Mechanical indentation testing of viable, stored articular cartilage. Arthritis Rheum 1979;22:1102-1108.
11 Rodrigo J, Thompson E, Travis C: 4 degree C preservation of avascular osteocartilaginous shell allografts in rats. Trans Orthop Res Soc 1980;5:72.

12 Onuma K, Urabe K, Naruse K, Park HJ, Uchida $\mathrm{K}$, Itoman M: Cold preservation of rat osteochondral tissues in two types of solid organ preservation solution, culture medium and saline. Cell Tissue Bank 2009;10:1-9.

13 Wayne JS, Amiel D, Kwan MK, Woo SL, Fierer A Meyers MH: Long-term storage effects on canine osteochondral allografts. Acta Orthop Scand 1990; 61:539-545

14 Oates KM, Chen AC, Young EP, Kwan MK, Amiel D, Convery FR: Effect of tissue culture storage on the in vivo survival of canine osteochondral allografts. J Orthop Res 1995;13:562-569.

15 Rohde RS, Studer RK, Chu CR: Mini-pig fresh osteochondral allografts deteriorate after 1 week of cold storage. Clin Orthop Relat Res 2004;427:226233. 
16 Williams RJ III, Dreese JC, Chen CT: Chondrocyte survival and material properties of hypothermically stored cartilage: an evaluation of tissue used for osteochondral allograft transplantation. Am J Sports Med 2004;32:132-139.

17 Kim W, Vacanti JP, Mooney D, Upton J, Ibarra C, Vacanti CA: Functional viability of chondrocytes stored at 4 degrees C. Tissue Eng 1996;2:75-81.

18 Teng MS, Yuen AS, Kim HT: Enhancing osteochondral allograft viability: effects of storage media composition. Clin Orthop Relat Res 2008;466: 1804-1809.

19 Lightfoot A, Martin J, Amendola A: Fluorescent viability stains overestimate chondrocyte viability in osteoarticular allografts. Am J Sports Med 2007; $35: 1817-1823$

20 O'Brien J, Wilson I, Orton T, Pognan F: Investigation of the alamar blue (resazurin) fluorescent dye for the assessment of mammalian cell cytotoxicity. Eur J Biochem 2000;267:5421-5426.

-21 Gu WY, Justiz MA, Yao H: Electrical conductivity of lumbar annulus fibrosis: effects of porosity and fixed charge density. Spine 2002;27:2390-2395.

22 Maroudas A: Physicochemical properties of cartilage in the light of ion exchange theory. Biophys $\mathrm{J}$ 1968;8:575-595.

23 Frank EH, Grodzinsky AJ, Phillips SL, Grimshaw, PE: Physiochemical and bioelectrical determinant of cartilage material properties; in Mow VC, Wood DO, Woo SL (eds): Biomechanics of Diarthrodial Joints, vol 1. New York, Springer, 1990, pp 261-282.
24 Gu WY, Yao H, Vega AL, Flagler D: Diffusivity of ions in agarose gels and intervertebral disc: effect of porosity. Ann Biomed Eng 2004;32:1710-1717.

25 Jackson A, Gu W: Transport properties of cartilaginous tissues. Curr Rheumatol Rev 2009;5:40-50.

26 Yao H, Gu WY: Convection and diffusion in charged hydrated soft tissues: a mixture theory approach. Biomechan Model Mechanobiol 2006;6: 2390-2395.

27 Brockbank KGM, Rahn E, Wright GJ, Chen Z, Yao H: Impact of Hypothermia upon Chondrocyte Viability and Cartilage Matrix Permeability during One Month of Refrigerated Storage. 19th Annual Congress of the European Association of Tissue Banks, Berlin, November 3-5, 2010, presentation.

28 Beaver RJ, Mahomed M, Backstein D, Davis A, Zukor DJ, Gross AE: Fresh osteochondral allografts for post-traumatic defects in the knee: a survivorship analysis. J Bone Joint Surg Br 1992;74: 105-110.

29 Bakay A, Csonge L, Papp G, Fekete L: Osteochondral resurfacing of the knee joint with allograft: clinical analysis of 33 cases. Int Orthop 1998; 22:277-281.

30 LaPrade RF, Botker J, Herzog M, Agel J: Refrigerated osteoarticular allografts to treat articular cartilage defects of the femoral condyles. A prospective outcomes study. J Bone Joint Surg Am 2009; 91:805-811.
1 Campbell CJ, Ishida H, Takahashi H, Kelly F: The transplantation of articular cartilage: an experimental study in dogs. J Bone Joint Surg Am 1963;45:1579-1592.

32 Enneking WF, Mindell ER: Observations on massive retrieved human allografts. J Bone Joint Surg Am 1991;73:1123-1142.

33 Malinin TI, Wagner JL, Pita JC, Lo H: Hypothermic storage and cryopreservation of cartilage. An experimental study. Clin Orthop Relat Res 1985;197:15-26.

34 Williams RJ, Ranawat AS, Potter HG, Carter T, Warren RF: Fresh stored allografts for the treatment of osteochondral defects of the knee. J Bone Joint Surg Am 2007;89:718-726.

35 Brockbank KGM, Taylor MJ: Tissue Preservation; in Baust JG, Baust JM (eds): Advances in Biopreservation. Boca Raton, CRC Press/Taylor and Francis, 2007, chapter 8, pp 157-196.

36 Brockbank KGM, Heacox AE, Schenke-Layland $\mathrm{K}$ : Guidance for removal of fetal bovine serum from cryopreserved heart valve processing. Cells Tissues Organs 2011;193:264-273.

37 Brockbank KGM, MacLellan WR, Xie J, HammAlvarez SF, Chen ZZ, Schenke-Layland K: Quantitative second harmonic generation imaging of cartilage damage. Cell Tissue Bank 2008;9:299-308. 